lemts apspriest, kāda ir viduslaiku piḷu loma mūsdienu sabiedrībā katrā no Baltijas piekrastes valstīm. Konferences "Castella Maris Baltici XV" beidzamās dienas rītā Krakovā bija noorganizēta konferences dalībnieku tikšanās ar Vāveles (Wawel) pils pētniekiem, kas iepazīstināja ar nozīmīgākajiem arheologiskajiem atsegumiem un to demonstrēšanu muzeja ekspozīcijā.

2017. gadā Vācijā notikušās konferences "Castella Maris Baltici XIV" rakstu krājuma iznākšana ir aizkavējusies, bet organizatori solīja to publicēt nākamgad. Tas, tāpat kā iepriekšējie "Castella Maris Baltici" sējumi, iznāks sērijā Archaeologia Medii Aevi Finlandiae (AMAF), ar kuras izdevumiem var iepazīties un tos pasūtìt Somijas viduslaiku arheologu biedrības mājaslapā http://www.skas.fi/in-english/amaf-series/.

Latvijas pārstāvju piedalīšanos konferencē "Castella Maris Baltici XV" Polijā finansiāli atbalstīja Valsts kultūrkapitāla fonds.

Ieva Ose

https://doi.org/10.22364/lviz.110.08

\title{
KONFERENCE “MIJIEDARBĪBA BALTIJAS LOKĀ BRONZAS LAIKMETĀ” HAMBURGĀ
}

2018. gada 22.-24. novembrī Hamburgas Universitātes Aizvēstures arheologiijas institūtā (Institut für Vor- und Frühgeschichtliche Archäologie) Vācijā notika bronzas laikmetam veltīta konference - Mijiedarbība Baltijas lokā bronzas laikmetā (Circum-Baltic interaction in the Bronze Age jeb saīsināti CIBA). Konference bija iedalīta trijos tēmu blokos: 1) dzīvesvietas un ekonomika; 2) materiālā kultūra un 3) robežas un sakari. Kopumā, neskaitot ievadrunas, tika prezentēti 18 pētījumi, kas skāra dažādus bronzas laikmetā notiekošos procesus Baltijas jūras regionā. Lai gan bronzas laikmetam un aizvēstures izpētei kopumā ik gadu veltītas dažādas konferences un simpoziji (piemēram, Nordic Bronze Age Symposium, EAA jeb Annual Meeting of the European Association of Archaeologists u.c.), tomēr šĩ ir pirmā, kurā uzsvars likts tieši uz Baltijas jūras reg̣ionu.

Pirmajā dienā ievadziņojumu par konferences idejas aizsākumiem sniedza Hamburgas Universitātes arheologs un profesors Franks Nikulka (Frank Nikulka). 2017. gadā tika izveidota darba grupa, kuru pārstāvēja bronzas laikmeta pētnieki no dažādām Baltijas jūras reg̣iona valstīm. Šajā sanāksmē tika izveidota konferences koncepcija un struktūra. Konferences 
galvenais mērķis bija veidot vienotu skatījumu uz procesiem bronzas laikmetā Baltijas jūras reg̣ionā. Konferenci organizēja Hamburgas Universitātes Aizvēstures arheologijas institūta pārstāvji - F. Nikulka, Daniela Hofmana (Daniel Hofmann) un Roberts Šumans (Robert Schumann). F. Nikulka iepazīstināja konferences dalībniekus ar nākamo runātāju - goda viesi dāņu arheologu Kristianu Kristiansenu (Kristian Kristiansen), viņa darbību, pētnieciskajām interesēm un zinātniskajiem sasniegumiem.

K. Kristiansens savā ziņojumā raksturoja bronzas laikmetā notikušās globalizācijas iemeslus un virzību. Pētnieks aplūkoja šo procesu ne vien Eiropas, bet arī citu teritoriju kontekstā, minot Anatolijas stepes, izcelıot Trialeti kultūru Gruzijas teritorijā un Kanešu Turcijas regiionā, kā arī Centrālāzijas regionu u.c. Arheologs raksturoja arī vilnas lielo nozīmi maiņas sakaru izplatības procesā, secinot, ka šis materiāls varētu būt bijis pat svarīgāks par bronzu. K. Kristiansens stāstīja par to, cik daudz dažādu resursu nepieciešams, lai uzturētu bronzas laikmeta kopienas, piemēram, aplūkojot kapu piedevas Jitlandē, to izstrādei, pēc arheologa aprēkiniem, bijis nepieciešams vismaz divas tonnas bronzas gadā, savukārt dzīvesvietas uzturēšanai vienai kopienai - vismaz 152 koki u.tml. Šos materiālus vajadzējis importēt masveidā, tādējādi kopā ar tirdzniecỉbu attīstījusies arī globalizācija.

Otrajā konferences dienā tika prezentēti ziņojumi, kuri saistīti ar pirmajiem diviem tēmu blokiem - dzīvesvietas un ekonomika un materiālā kultūra. Kīles Universitātes pārstāvji Stefānija Šefere (Stefanie Schaefer), Juta Kneizela (Jutta Kneisel) un Ingo Fēzers (Ingo Feeser) ziņoja par apdzīvotības pēdām Baltijas jūras dienvidrietumos, kā piemēru minot Mangu de Bargenu (Mang de Bargen), kur apdzīvotība ilgusi no vēlā neolìta lìdz pat senākajam dzelzs laikmetam. Tomēr bronzas laikmeta apdzīvotības pēdas ir salīdzinoši slikti saglabājušās atšķirībā no apbedījumiem - fiksēts 21 urnu apbedījumu uzkalniņšs. Arheologi raksturoja divas konstatētās transformāciju fāzes: 1) 1600/1500 g. p.m.ē., izmantojot ekologiskos datus kopā ar arheoloǵiskajiem, autori identificējuši izmaiņas dzīvesvietu struktūrā, ko saista ar sociālekonomiskiem apstākḷiem; 2) $1300 / 1200$ g. p.m.ē. konstatētas izmaiņas apbedījumu izveidošanā, ko saista ar ideologiskiem un ekonomiskiem apsvērumiem.

Par to, ko nozīmē centrs bronzas laikmetā un vai tas ir saistāms ar maiņas sakariem, stāstīja Getingenes Universitātes pārstāvis Immo Heske (Immo Heske), balstoties uz pētījumiem vēlā bronzas laikmeta Hīnenburgas (Hünenburg) pilskalnā, kurš ticis apdzīvots aptuveni 500 gadus. Tā kā pilskalnā atrasti dažādi bronzas priekšmeti - ne vien lokāli, bet arī 
importēti no citiem reǵioniem, tas tiek pieskaitīts pie centra. I. Heske kopumā pilskalnus saista ar eliti, kura izvērsusi savstarpējus sakarus. Viņš atzīmēja arī trīs procesus, kas spēj padarìt dzìvesvietu par centru: 1) tirdzniecība, 2) rituāli un 3) spēles. I. Heske uzsvēra, ka, lai gan šādi procesi konstatējami arī apmetnēs, tām nav tik plaši izvērsti sakari kā pilskalniem, līdz ar to nav iespējams šāda tipa dzīvesvietas uzskatīt par centriem.

Aḷgimants Merkevičs (Algimantas Merkevičius, Viḷnnas Universitāte) ziņoja par pilskalnu izveidošanās iespējamajiem iemesliem Austrumbaltijas regiiona dienvidos, izdalot divas iemeslu grupas: 1) iekšêjie, kas ietver ekonomiskos (lauksaimniecība un metālapstrāde), sociālos (sociālā diferenciācija) un ideoloǵiskos (mirušo kremācija, depozìti) aspektus; 2) ārējie, kas ietver cilvēku pārvietošanos un maiņas sakaru attīstību, kā arī karadarbību un aizsardzību.

Ķìles un Berlīnes universitāšu pētnieki Inese Beilke-Foigta (Ines Beilke-Voigt), Olivers Nakoincs (Oliver Nakoinz) un J. Kneizela skaidroja bronzas un dzelzs laikmeta pilskalnu funkciju un nozīmi sabiedrībā. Pētnieki uzsvēra, ka pilskalns ir monofunkcionāla dzīvesvieta un bieži vien tā funkciju mēdz aplami uztvert vienpusēji, respektīvi, pilskalni izveidoti un kalpojuši tikai aizsardzības nolūkiem. Pilskalnu kā dzīvesvietu arheologi saista ar funkciju (statusa simbols, aizsardzība), subjektu (cilvēks sabiedrība - institūcija) un iemeslu (kopienas saiknes, drošības sajūta). Tādējādi pilskalni pilnā mērā atspoguḷo sociālos, ekonomiskos un kultūras procesus kopienā.

Katarina Slusarska (Katarzyna Ślusarska, Gdaṇskas Universitāte) stāstīja par vēlā bronzas uz agrā dzelzs laikmeta apdzīvotību Oderas lejtecē un lagūnas regiionā. Balstoties uz geologisko kontekstu, keramikas izplatību, apbedījumiem, kā arī uz depozìtiem un putekšņu analīzēm, autore izdalīja divus galvenos apdzīvotības regionus: Ūzedomas un Volinas salas Baltijas jūrā un Voltinas un Pižices zemieni.

Arheologi Vanda Visocka (LU), Ūve Sperlings (Uwe Sperling, Rostokas Universitāte) un Vìtenis Podens (Vytenis Podènas, Viḷnas Universitāte) ziņoja par Austrumbaltijas vēlā bronzas laikmeta keramikas izgatavošanas stilistiskajiem un tehnologiskajiem aspektiem. ${ }^{1}$ Pētijums balstîts uz triju pilskalnu materiālu - Asvas (Igaunijā), Ķivutkalna (Latvijā) un

1 Pētījums tapis ar Valsts kultūrkapitāla fonda finansiālu atbalstu. Projekta nosaukums: "Austrumbaltijas keramikas stilistika un tehnologiskie aspekti vēlajā bronzas laikmetā: Asvas, Ķivutkalna un Narkūnas pilskalnu piemērs” (projekta Nr. 2018-3KMA001-P). 
Narkūnas (Lietuvā). Pētnieki secināja, ka, lai gan Narkūnas keramika pieder pie švīkātās keramikas arheologiskās kultūras, pēc citām stilistiskajām iezīmēm tā atšḳiras no Asvas un Ķivutkalna. Tomēr keramikas tehnologiskie aspekti bijuši līdzīgi visos pilskalnos.

Kamila Novaka (Kamil Nowak, Vroclavas Universitāte) sniedza ieskatu par metālapstrādi Rietumpomerānijā un Mēklenburgas reǵionā. Kopumā izpētīts materiāls no 31 dzīvesvietas un vairākiem depozìtiem. Pētniece secināja, ka metālapstrādes pēdas konstatējamas ne vien dzīvesvietās, bet arī depozītos, kur atrasta neapstrādāta bronza.

Rostokas Universitātes pārstāvji Ū. Sperlings un Hanss Jergs Karlsens (Hans-Jörg Karlsen) prezentēja pirmos pētījuma rezultātus par metālapstrādi Asvas pilskalnā Igaunijā. Asvas pilskalnā atrasts vairāk nekā tūkstotis lejamveidṇu, tādējādi tas bijis spēcīgs bronzas apstrādes centrs. Pēc pašreizējiem rezultātiem arheologi secināja, ka metālapstrādē bijusi ziemeḷu reǵionu ietekme, taču lejamveidnes izgatavotas uz vietas. Tāpat arī bronza lieta un apstrādāta uz vietas pilskalnā, par ko liecina atrastie vara izdedži.

Hamburgas Universitātes (Hella Hartena-Buga (Hella Harten-Buga), Birte Mellere (Birte Meller), F. Nikulka), Getingenes Universitātes (Tomass Terbergers (Thomas Terberger)) un Šverīnes Universitātes (Detlefs Jancens (Detlef Jantzen)) pārstāvji sadarbībā ar Jergu Oršìtu (Jörg Orschiedt) stāstīja par Tollenzē ielejā atrastiem krama bultu galiem, to pielietojumu un izmantošanu kaujā. No 10 atrastajiem krama bultu galiem pieci tika analizēti, izmantojot gan organisko atlieku analīzes, gan digitālo mikroskopiju. Uz viena bultas gala konstatētas zīdītāja asinis (iespējams, cilvēka), uz cita - bronzas atliekas, vēl uz kāda - muskuḷu audi. Pētnieki secināja, ka šie bultu gali izmantoti kaujā, nevis medībās.

Trešajā konferences dienā tika prezentēti ziņojumi, kas skāra robežas un mijiedarbību bronzas laikmetā. Helle Vandkilde (Helle Vandkilde, Orhūsas Universitāte) pievērsās "bronzizācijas" koncepcijas jeb bronzas laikmeta kā visaptveroša globalizācijas fenomena raksturojumam. Arheologe skaidroja, ka līdz ar bronzas materiāla importēšanu un eksportēšanu radās dažādu kultūru saiknes, veidojās urbānie un neurbānie regioni, arī protozīda ceḷa nomadi. Visi šie procesi noveda līdz globalizācijai. Autore savu ziņojumu noslēdza ar tēzi, ka bronzizācija ne vien izmainīja tradīcijas, bet arī radīja nevienlīdzību kopienās.

Valters Langs (Valter Lang, Tartu Universitāte) skaidroja protosomugru etnosa iespējamo izveidošanos, kopienu pārvietošanos un tradīciju maiṇu. Lai gan Igaunijas teritorijā bronzas laikmetā dzīvojušās kopie- 
nas bijušas genētiski viendabīgas, tās pēc materiālās kultūras bijušas ḷoti atšḳirīgas. Šādas materiālās kultūras un tradīciju atšķirības pētnieks saista ar jaunu kopienu pieplūdumu/pārcel̦ošanu no viena reǵiona uz citu, kā arī ar maiņas sakariem un savstarpējiem kontaktiem.

Jans Heinrihs Bunnefelds (Jan-Heinrich Bunnefeld, Getingenes Universitāte) ziņoja par Baltijas jūras regionā atrastajiem zobeniem, kas datējami ar agro bronzas laikmetu. Zobenu izplatîba ir l̦oti nevienmērīga, piemēram, Skandināvijā un Vācijas piejūras reǵionos atrasti vairāk nekā divi tūkstoši, citos reǵionos daudz mazāk. Zobenu un dunču ornaments dažādos reǵionos ir ḷoti atšķirīgs - teritorijā no Pomerānijas līdz Somijai tie ir ar daudz vienkāršāku stilistiku nekā ziemeḷos. Šobrīd nav iespējams interpretēt šo tendenci. Arheologs arī konstatējis, ka dzīvesvietās atrastie zobeni ir atšķirīgi no apbedījumos atrastajiem.

Getingenes Universitātes pārstāvji Lorencs Rāmštorfs (Lorenz Rahmstorf) un Nikola Jalongo (Nicola Ialongo) stāstīja par rievotiem akmens priekšmetiem. Pētnieki šos priekšmetus, pēc dažādām analogijām, interpretē kā svaru atsvariṇus jeb tā dēvētos rīlenšteinus (rillensteine). Lai klasificētu šāda veida artefaktus, arheologi testēja to balansu, izmantoja arī kvantogrammas un Monte Karlo metodes. Analizējot 521 akmens atsvariṇu, pētnieki izdalīja četrus izplatîbas regionus: 1) Britāniju; 2) Spāniju; 3) Centrāleiropu un 4) Melnkalnes teritoriju. Atsvaru svars dažāds - no 20 gramiem līdz pat 5 kilogramiem. Atsevišķos depozītos Prūsijā arī atrasti atsvari, kas varētu liecināt par dažādiem tirdzniecības aspektiem. Pētnieki vērsa uzmanību, ka dažādos reǵionos visticamāk bijušas atšķirīgas svēršanas sistēmas. To izzināšanu apgrūtina rakstīto avotu neesamỉba.

Šverīnes (D. Jancens), Getingenes (T. Terbergers) un Greifsvaldes Universitātes (Ūte Brinkere (Ute Brinker), Gundula Lidke (Gundula Lidke)) pārstāvji prezentēja pirmos pētījuma rezultātus saistībā ar karadarbību Tollenzē ielejā ap 1300.-1250. g. p.m.ē. Tollenzē upe bijusi nozīmīga maǵistrāle. Pēc geoloǵiskajiem datiem konstatēts, ka upe senatnē bijusi platāka un seklāka nekā šodien, tāpēc to bijis iespējams šķērsot. Tajā konstatētas koka konstrukcijas paliekas, kas datējamas ar 14. gs. p.m.ē. Atrasti arī dažādu ieroču fragmenti - bultu gali, koka mieti u.tml. Pētnieki skaidroja, ka kaujai bijis "skriešanas" raksturs no dienvidiem uz ziemel̦iem. Kaujas kulminācija notikusi Velcinas (Weltzin) apkaimē. Šobrīd atrastas 144 kauju dalībnieku mirstīgās atliekas, taču tiek lēsts, ka kaujās, iespējams, piedalījušies gandrīz divi tūkstoši cilvēku. Pēc DNS analīzēm tā bijusi ḷoti heterogēna, lokāla populācija, kurai, spriežot pēc 
izotopu analīzēm, bijusi dažāda diēta. Savukārt ķīmiskajās analīzēs konstatēts, ka ieročiem izmantotais metāls nācis no Austrumalpu un Karpatu regioniem.

Ķīles Universitātes pārstāvji Annalēna Boka (Annalena Bock) un Hendriks Rēze (Hendrik Raese) ziņoja par kultūru robežreǵioniem Baltijas jūras dienvidrietumu teritorijā pārejas posmā no neolīta uz bronzas laikmetu. Autori galvenokārt koncentrējās uz Ūņetices kultūru. Dzīvesvietās, kurās pārstāvēta šì kultūra, kā maiņas priekšmetus lietoja dzintaru un metālu. Atrastajos depozītos novērojama maiņa no vēlā neolīta uz agro bronzas laikmetu. Analizējot Dienvidskandināvijā un Centrāleiropā konstatēto 365 metāla depozītu saturu, autori izdalīja trīs veidus: 1) ar dažādiem priekšmetiem bagāti, 2) ar maz māla priekšmetiem un 3) mitrā vidē (purvos u.tml.) bez māla priekšmetiem. Arheologi pēc dzīvesvietu un depozītu korelācijas, kā arī izmantojot prediktīvās modelēšanas metodi, secināja, ka kultūru robežregioni konstatējami ik pēc aptuveni 30 kilometriem.

Marcins Macejevskis (Marcin Maciejewski, Vroclavas Universitāte) stāstīja par vēlā bronzas un agrā dzelzs laikmeta depozītiem kā robežregiionu pāreju. Viņš izdalīja divu veidu depozītus: 1) rituālu (rituālā un sociālā funkcija), 2) nerituālu (politiskā un ekonomiskā funkcija). Kališas reǵionā konstatēts depozìts akmens šķirstā, līdzīgs atrasts arī Rosko. Pētnieks secināja, ka šādas konstrukcijas saistītas nevis ar apbedīšanas tradīcijām, bet gan ar depozìtu funkcionālo nozīmi. Autors izcēla arī Kovalefko depozītu, kurš atrasts purvainā vidē pie nelielas upes starp diviem kultūru robežregioniem. Savukārt Šuzefko depozīts atrasts pie jūras. Tādējādi pētnieks šāda veida depozītus interpretēja kā robežzīmes.

Joakims Vēlins (Joakim Wehlin, Upsalas Universitāte) ziņoja par akmens laivveida krāvumiem, īpaši koncentrējoties uz Gotlandi. Šāda tipa apbedījumi saistāmi ar jūrniekiem un tirdzniecību. Arheologs Gotlandi interpretēja kā maiṇas sakaru punktu, kurā norisinājušās arī sociāla rakstura aktivitātes, par ko liecina fakts, ka visi uz salas esošie pieminekḷi atrodas netālu no jūras.

Agne Čivilīte (Agné Čivilytè, Viḷnas Universitāte), runājot par Austrumbaltijas nozīmi bronzas laikmetā, pievērsās jautājumam, vai šo regionu iespējams dēvēt par perifēriju. Aizvēstures pētnieki par bronzas laikmeta centru Baltijas jūrā uzskata Skandināviju, citi reg̣ioni zināmā mērā bijuši politiski un ekonomiski atkarīgi no tās. Savukārt Baltijas valstu teritorija tiek raksturota kā ziemeḷu kultūru perifērija. Arheologe uzskata, ka Baltijas valstu reǵionu nedrīkst uzskatìt par perifēriju, vismaz sākot no vēlā bronzas laikmeta, kad notikuši aktīvi maiņas sakari un pa- 
stāvējušas vairākas kultūras, kurām bijušas savas tradīcijas un ideoloǵiskie uzskati.

Konferences noslēgumā uzstājās Norvēgijas institūta Romā direktors, vēlā neolīta un agrā bronzas laikmeta pētnieks Kristofers Preskots (Christopher Prescott). Prezentētajos pētījumos K. Preskots saskatījis divus galvenos ziṇojumu blokus: 1) kopaina par Baltijas jūras regiionu un tā fragmentārisms un 2) saikne starp diviem reǵioniem - ziemeḷiem un mūsdienu Baltijas valstu teritoriju. Arheologs akcentēja, ka šajā konferencē pietrūcis ziṇojumu un diskusiju par Volgas reǵionu un tā saikni ar Baltijas jūras regiionu. Balstoties uz prezentētajiem pētỉjumiem, plānots izdot konferences rakstu krājumu.

Vanda Visocka 